\title{
Determinants of Demand for Credit among Wheat and Teff Smallholder Farmers in Central of Ethiopia (Arsi and South West Shewa)
}

\author{
Efa Gobena Tura*, Tadesse Kenea ${ }^{1}$ and Tura Kaso ${ }^{2}$
}

${ }^{2}$ Department of Agribusiness and Value Chain Management, Ambo University, Ambo, Ethiopia

${ }^{1}$ Division of Logistics, Department of Energy and Technology, Swedish University of Agricultural Sciences efagobena@gmail.com

Received Date: November 18, 2016 Accepted Date: November 30, 2016

Published Date: June 12, 2017

Abstract: The greatest challenge to food security is low productivity emanating from slow growth in the agricultural sector and one of the reasons for this is little or no access to financial resources by producers. This paper assesses the determinants of farmer's credit demand among wheat and teff farmers in Central parts of Ethiopia. We pay particular attention to identifying credit demanded by smallholder farmers. The qualitative and quantitative types of data were collected from primary sources of data randomly from 150 teff growers. Multiple regression models were used to analysis the determinate of demand for credit by small holder's farmers. The impacts of household characteristics on credit demand, we estimate a multiple regression model.There is no uniform access to formal credit across rural communes in Ethiopia, although quantitative rationing does exist. The results showed that demand for credit by teff smallholders are affected positively by education status, dependency ratio, low interest rate, farm size and long payment period, while the sources of loan if it is business partner affected the amount of credit demanded by teff farmers negatively. The amount of credit demanded by wheat farmers were affected negatively by sex and sources of loan if it is business partner, whereas independent variables such as education status, farm size, long repayment period, low interest rate and access to training were affecting amount of credit demanded by wheat farmers positively. The problem of limited screening power and asymmetric information is revealed in the result that the further the distance from a commune to a bank branch, the less likely a formal bank will lend to residents of that commune. Prediction of formal credit demand is estimated reducing over the years suggesting lack of investment opportunity for rural households. With respect to policy implications, the study suggested that the government could expand other programs like job creation or vocational training, and could introduce a policy calling for more investment in far and distant rural areas to enable farmers' access to credit.

Keywords: Credit, Multiple regression models, Arsi, Teff, Wheat

\section{INTRODUCTION}

Agriculture continues to be a fundamental instrument for sustainable development and poverty reduction' yet, 'financial constraints in agriculture remain pervasive, and they are costly and inequitablydistributed, severely limiting smallholders' ability to compete'. Sudden and dramatic changes in food prices have exposed the vulnerability of agricultural production in meeting global demand and call for increased investment in agriculture at all levels. The question is how the right amount of investment can be acquired, particularly in a challenging milieu where financial uncertainty causes a reduction in available resources along with increased fear and scrutiny of risk. An answer to addressing these constraints goes beyond conventional measures since 
Determinants of Demand for Credit among Wheat and Teff Smallholder Farmers in Central of Ethiopia (Arsi and South West Shewa)

agriculture has always been difficult to finance through formal financial institutions and approaches. In a global economy, livelihoods are no longer simply dependent upon what one produces, but also how that production fits with competitive chains in the market system. The emphasis on global systems that has developed is usefulin the context of understanding the intricacies of each chain even at the local level. Even so, from a livelihood perspective as well as a financial viewpoint, it is important to understand the status of a chain from the advantage of each participant within a chain (World Bank, 2008).

The environment for agricultural finance is further influenced by the growing concentration of control in the agricultural sector. Driven by gains from economies of scale and globalization of the food chain along with access to resources, multinational and other interconnected agribusinesses have a greater impact in a sector that is characterized by increasing vertical and horizontalintegration. The consequences of tightening integration are profound, especially for smallholders and others who are outside of the interlinked chains. In short, agriculture is evolving towards a modern, extremely competitive system driven by consumer demand for higher value, more processed products, and consistent quality and safety standards. Hence, enhancing smallholders' productivity, competitiveness and their participation in these global value chains have been noted as priorities of the agriculture-for-development agenda (World Bank, 2008).

Agricultural value chain finance offers an opportunity to reduce cost and risk in financing, and reach out to smallholder farmers. For financial institutions, value chain finance creates the impetus to look beyond the direct recipient of finance to better understand the competitiveness and risks in the sector as a whole and to craft products that best fit the needs of the businessesin the chain. Naturally, this more comprehensive approach to agricultural financing is not unique to value chain finance; some leading financial organizations in the sector employ such a focus in their loan assessment processesbut this is more often not the case. In fact, much of the finance available to value chains is not from financial institutions but rather from others within the chain. At the same time, value chain finance can help the chains become more inclusive, by making resources available for smallholders to integrate into higher value markets. Finance that is linked with value chains is not new and some types of trader finance, for example, have been around for millennia; what is new is the way it is being applied more systematically to agriculture, using innovative or adapted approaches, tools and technologies.

In Ethiopia, the rural financial system is dichotomous in nature. The formal and informal sectors co-exist, with differences in accessibility. The two sources continue to be the major sources of agricultural credit, though their proportion differs. According to Singh (1993) the basic distinction between the formal and informal sectors is that the latter operates outside the rules and regulations imposed on the farmer by the formal financial institutions. Formal and informal credits are imperfect substitutes. In particular, formal credit, whenever available, reduces, but not completely eliminates, informal borrowing. This suggests that the two forms of credit fulfill different functions in the household's inter-temporal transfer of resources.

Commercial banks and other formal institutions fail to cater to the credit needs of smallholders, however, mainly due to their lending terms and conditions. It is generally the rules and regulations of the formal financial institutions that have created the myth that the poor are not bankable, and since they can't afford the required collateral, they are considered unaccredited worthy (Adera, 1995). Despite efforts to overcome the widespread lack of financial services, especially among smallholders in developing countries, and the expansion of credit in the rural areas of these countries, the majority still have only limited access to bank services to support their private initiatives (Braverman and Guasch, 1986).

In Ethiopia, several microfinance institutions (MFIs) have been established and have been operating towards resolving the credit access problem of the poor particularly those who engage in petty business (Befekadu, 2007). Microfinance outreach is still so low in Oromia region or elsewhere in Ethiopia. There are many economically active poor people still un-reached (Getaneh, 2005a).

American Research Journal of Business and Management

Page 2 
Determinants of Demand for Credit among Wheat and Teff Smallholder Farmers in Central of Ethiopia (Arsi and South West Shewa)

Credit provision is one of the principal components of rural development, which helps to attain rapid and sustainable growth of agriculture. Rural credit is a temporary substitute for personal savings, which catalyzes the process of agricultural production and productivity. To boost agricultural production and productivity farmers have to use improved agricultural technologies. However the adoption of modern technologies is relatively expensive and small farmers cannot afford to self-finance. As a result, the utilization of agricultural technologies is very low. It is argued that enhanced provision of rural credit would accelerate agricultural production and productivity (Briquette, 1999).

In Ethiopia there is a wide gap between owned and required capital to finance the agricultural activities of small holder farmers since the income from subsistence agriculture does not yield much surplus beyond family consumption and other social obligations. The lack of access to capital in rural areas is one of the major factors which hinder the development of agriculture. In the Ethiopia, central part until a few years ago land was not a problem. But labor is in short supply and is expensive especially during peak weeding and harvesting periods. Farmers mostly use hired labor. This indicates that there is a high demand for cash during the peak periods for labor. Due to the fact that the formal sector is not in a position to satisfy the credit requirements of the farmers during the periods, they depend on the informal sector for their credit needs. Most informal lenders provide cash advance before the crop is harvested, farmers are then obliged to repay the loan in cash or in kind based on previous commitment made with the lender. Theoretical and empirical evidence in the region show that in the past years formal credit institutions failed to reach the poor, particularly women and the very poor households (Tefera, 2004).

Within a supply chain involving more than one company, there is dilemma between different supply chain actors working to obtaining the same type of financial improvement (Hofmann and Kotzab, 2010). For example, extending payment terms transfers cost of capital and risk to other actors in the supply chain. While the buyer may experience lower credit risk, the supplier needs additional financing to cover the lengthened period without payment for their delivered goods and services. In situations where suppliers have restricted access to short-terms financing, the shifting costs can lead to serious consequences for the supplier and the buying company. Less stable suppliers result in increased supplier base risk as suppliers can be forced to delay their purchasing, cut back on inventories and hold back on service levels and quality processes. Eventually, increased costs and reduced quality for the suppliers will likely be included in the buying firm's cost for purchased goods (Hofmann and Kotzab, 2010).

According to McKinsey (2015) payables in value chain finance programs has grown with 20 percent per year since 2010 and is expected to grow by 15 percent per year the next five years. At the same time, value chain finance (VCF) providers see a growing interest from SMEs with many implementing a VCF solution. The increasing demand in VCF means increased need for corporations to analyze if and how a VCF fit their business. VCF is a broad field, including as the name suggests, the supply chain dimension as well as a financial dimension. This is often two areas within organizations that are separated from each other, making a VCF evaluation difficult to approach.

Financing of all agricultural value chain actors specifically wheat and teff producer requires liquid cash that often is not readily available with the smallholder farmers. Therefore, it is essential to expand the status of rural credit at large to improve agricultural productivity. This study was intended to deal with the following objective:

1. To identify factors influencing the demand for credit by small holder farmers of wheat and teff farmers 
Determinants of Demand for Credit among Wheat and Teff Smallholder Farmers in Central of Ethiopia (Arsi and South West Shewa)

\section{Agricultural Value Chain Finance Instruments}

There are many ways to categorize the modalities, and describe the various financial products and tools that can be used. Wenner (2006), for example, states that the main modalities of value chain financing are: trade finance, secured transactions, risk management and financial enhancement instruments. According to the analysis of the practical application of the various mechanisms the instruments by product financing, receivables financing, physical asset collateralization, risk mitigation and structured enhancements, and provides illustrated descriptions of the most common products. It must further be noted that the use of terms vary somewhat between countries and even across sectors. In some contexts, a precise legal term may be applied, but the use of the terms in agriculture may often encompass a broader meaning and application.

\section{Smallholder Farmers Access to Formal Credit}

Penchansky and Thomas, (1981), stated that "to some authors "access" refers to entry into or use of the health care system, while to others it characterizes factors influencing entry or use." Moreover, according to the free on line dictionary (undated), access can be defined as, the right to obtain or make use of or take advantage of something (as services or membership). Diagne et al., (2000) stated that a household is said to have access to a type of credit if at least one of its members has a strictly positive credit limit for that type of credit. Similarly, a household is classified as credit constrained for a type of credit if at least one of its members is constrained for that type of credit.

Access to financial services by smallholders is normally seen as one of the constraints limiting their benefits from credit facilities. However, in most cases the access problem, especially among formal financial institutions, is one created by the institutions mainly through their lending policies. This is manifested in the form of prescribed minimum loan amounts, complicated application procedures and restrictions on credit for specific purposes. For small-scale enterprises, reliable access to short-term and small amounts of credit is more valuable, and emphasizing it may be more appropriate in credit programmes aimed at such enterprises (Schmidt and Kropp, 1987).

Women are frequently discriminated against in formal credit markets in developing countries. The belief in discrimination against women in formal credit markets, often based upon the limited number of women borrowers in the market, is perceived as an outcome of lenders' rejection of women's applications for loan contracts. Over a decade ago "two major factors which restrict women's access to formal credit more than men's. This was related to women lack of control over economic resource and nature of their economic activity"(Buvinic et al., 1979). On the other hand, a decade later, researchers are still trying to clarify the reasons that limit women's access to formal credit. In her assessment of credit as the missing piece in micro enterprise development, emphasized the gender-based credit constraints, such as limited education, inferior legal status and unpaid reproductive responsibilities exacerbated the problems women face when operating small businesses (McKee, 1989).

In another attempt to evaluate women's access to credit, Lycette and White (1989), noted that there is little direct evidence of women's limited access to credit. The authors argued that it is difficult to carefully analyze the problem because many formal financial institutions do not keep records of financial transactions by gender since women are such a small proportion of their clients. Nonetheless, based on a few case studies, the authors reported that women small-business owners, in both urban and rural areas, face problems with regard to credit that men do not experience. The perception that formal financial institutions discriminate against women 
Determinants of Demand for Credit among Wheat and Teff Smallholder Farmers in Central of Ethiopia (Arsi and South West Shewa)

does not only focus on developing countries in Africa, Asia and Latin America. This view is also pervasive in developed countries. A large literature treats the issue of bank discrimination against female business owners in Western countries, but the measurement of discrimination is largely based on subjective perceptions and lacks statistical support (Stevenson, 1986).

A number of factors explain why certain borrowers prefer to use credit. Factors related to the participation of credit users in the credits market were therefore investigated. Such factors can be divided into borrowers characteristics, and the loan terms and conditions imposed by lenders (Kashuliza and Kydd, 1996; Zeller, 1994). Schmidt and Kropp (1987) revealed that the type of financial institution and its policy will often determine the access. Where credit duration, terms of payment, required security and the provisions of supplementary services do not fit the needs of the target group, potential borrowers will not apply for credit even where it exists and when they do, they will be denied access. In addition, Bigsten et al. (2003), and fliesig (1995), stated that in developing countries asymmetric information, high risks, lack of collateral, lender-borrower distance, small and frequent credit transactions of rural households make real costs of borrowing vary among different sources of credit.

A study by Atieno (2001), indicates that income level, distance to credit sources, past credit participation and assets owned were significant variables that explain the participation in formal credit markets. Hussien (2007), also indicated that Farm households are more likely to prefer the informal sector to the formal sector with respect to flexibility in rescheduling loan repayments in times of unexpected income shocks. This was also supported by Padmanabhan (1996), comparing the informal credit sector from the formal stated that proximity, comfortable atmosphere, quick credit, all times access, freedom of deployment, repayment flexibility and lower transaction costs are the advantages of the informal sector have made them almost indispensable, particularly to small farmers.

According to Hossain (1988), the Grameen Bank experience shows that most of the conditions imposed by formal credit institutions like collateral requirements should not actually stand in the way of smallholders and the poor in obtaining credit. The poor can use the loans and repay if effective procedures for disbursement, supervision and repayment have been established. On the other hand, Getaneh (2005a), stated that group lending approach effectively ration out some groups of farm households (The poorest of the poor). That is coborrowers tend to self select themselves into a group of homogenous members that effectively discriminates against some others to reduce risk of carrying the burden of repayment in case of defaults of co-borrowers.

Access to formal credit can also be affected by household characteristics. As stated by Hussien (2007), the probability of choosing the formal credit sector was positively affected by gender, educational level, household labor and farm size. He further explained that education, credit information and extension visit are more likely to increase the information base and decision making abilities of the farm households including the ability to compare pros and cons of choosing appropriate credit and production technology.

In another study, based on the data from a sample survey of 699 randomly selected peasant farmers in Bolivia, Miller and Ladman (1983), applied discriminant analysis to identify a set of socio-economic, physical and psychological factors that influence credit use among small farmers with a view to differentiate between borrowers, potential borrowers, and non-borrowers. The results of the study indicated that borrowers were characterized by higher resource base, farm size, higher level of education, large number of cattle, higher household incomes, higher level of market integration, greater use of improved technology, larger operating costs and investments, higher risk ability, etc. Potential borrowers were characterized by further distance from 
Determinants of Demand for Credit among Wheat and Teff Smallholder Farmers in Central of Ethiopia (Arsi and South West Shewa)

markets, low level of market integration, higher transaction costs, less number of cattle, etc. Furthermore, non-potential borrowers were characterized by lack of interest to expand production, lower level of education, limited use of improved technology, shortage of labour and proximity to market.

Physical distance of farm households from formal lending institutions is one of the factors that influence access to formal credit. According to Hussien (2007), farm households are discouraged to borrow from credit sector if it is located farther. This is because both temporal and monetary costs of transaction, especially transportation cost, increase with lender-borrower distance which raises the effective cost of borrowing at otherwise relatively lower interest rate in the sector. A study in Egypt by Mohieldin and Write (2000), employing a probit model analysis of the formal credit sector shows the impact of the explanatory variables on the outcome of whether a person has a loan. Both the requirements of the individual (demand side) and of the lending institution (supply side) determined whether a loan is extant. The results of the study indicated that educational level, ownership of land, total assets, and sizes of the household were significant factors.

Assefa (1989), empirically tested a set of socio-economic and other important factors influencing agricultural credit use among small farmers aimed at differentiating borrowers from non-borrowers. Using discrimnant analysis, Assefa found that large farm size, high investment, adoption of improved technology were significant variables in distinguishing borrowers from non-borrowers.

Hussien (2007), in his study also found out that the use of extension package, in effect, requires adequate labor supply, thus a positive effect of household labor on the choice of formal credit for the farm input. The choice of the formal sector increases with the number of productive members of the farm households. It was also indicated that the low level of education of the farm households may have contributed for limited use of formal sector credit by farm households. Men tend to borrow more from the formal and semiformal sources than women do. That is being a female reduces the likelihood of borrowing from the formal and semiformal credit sectors where it increases the probability of borrowing from the informal credit sources.

\section{MethodologY}

\section{Description of Study Area}

This study was undertaken in central Part of Ethiopia in two potential zone (namely Arsi and South west Shoa of Oromia regional state) in wheat and Teff production respectively.

\section{Arsi Zone}

Tiyo: is one of Administrative unit under Oromia Regional State, Southeast Ethiopia, Part of the Arsi Zone. Tiyo district is located about $154 \mathrm{Kms}$ southeast of Addis Ababa and Asella town, the capital of Arsi Zone is found in this district

Hetosa: Hetosa district ${ }^{1}$ is one of Administrative unit under Oromia Regional State, Southeast Ethiopia, part of the Arsi zone. Hetosa district is located about $123 \mathrm{Kms}$ southeast of Addis Ababa and 50kms northeast of Asella town, the capital of Arsi Zone of Oromia Region.The agro- ecology in Hetosa comprises highland (20\%), midland (48\%) and lowland (32\%) agro climatic zones. The temperature varies between $14 \mathrm{C}^{0}-27 \mathrm{C}^{0}$.

1 District is the fourth level in Ethiopian formal administrative structure next to Federal and Regional level governments. 
Determinants of Demand for Credit among Wheat and Teff Smallholder Farmers in Central of Ethiopia (Arsi and South West Shewa)
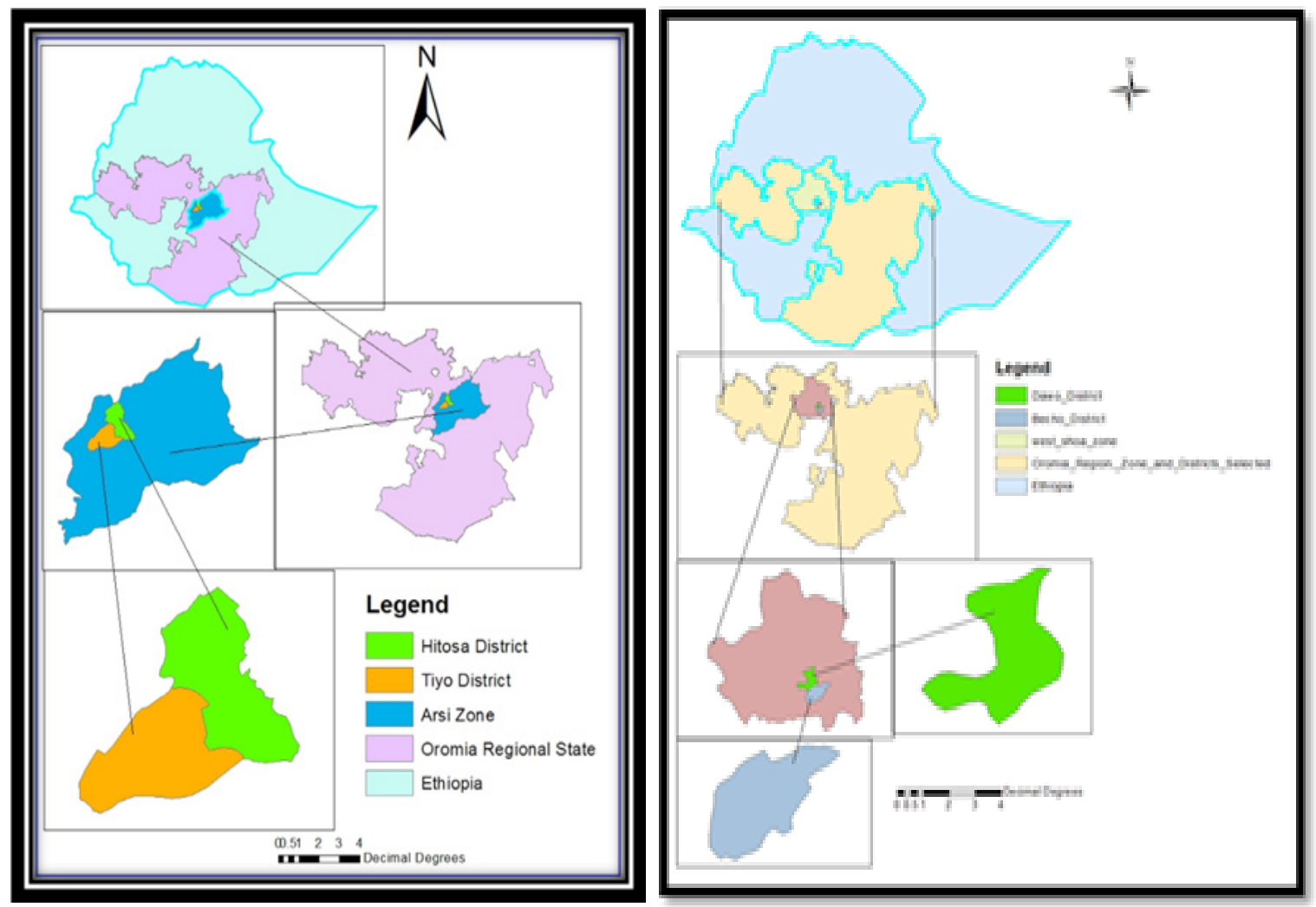

Fig1. map of study area

Source: Adopted and manipulated from Ethiopian map (2016)

\section{South West Shewa Zone}

The study was conducted in two districts of south-west Shewa zone (Oromia region) namely, Becho and Dawo district. Becho and Dawo district are located at latitude/longitude of $8^{\circ} 35^{\prime} \mathrm{N} 38^{\circ} 15^{\prime} \mathrm{E}$ and $8^{\circ} 45^{\prime} \mathrm{N} 38^{\circ} 10^{\prime} \mathrm{E}$, and at about $80 \mathrm{~km}$ and $96 \mathrm{~km}$ from the capital Addis Ababa, respectively.

Dawo is one of the districts in the Oromia Region of Ethiopia. Dawo is bordered on the southwest by Waliso, on the west and north by Dendi, on the east by Elu, and on the southeast by Becho. The administrative town in Dawo district is Busa. Dawo is well known for its quality teff, which is marketed in Addis Ababa. The 2007 national census reported total populations for this district were 84,336, of whom 42,815 were men and 41,521 were women; 3,779 or $4.48 \%$ of its population were urban dwellers. The two largest ethnic groups in Dawo district were the Oromo (93.35\%), and Amhara (6.17\%); all other ethnic groups made up $0.48 \%$ of the population. Oromiffa was spoken as a first language by $98.04 \%$, while $1.88 \%$ spoke Amharic; the remaining $0.48 \%$ spoke all other primary languages (CSA, 2007).

Becho is one of the districts in the Oromia Region of Ethiopia. Becho is bordered on the south by Kokir, on the west by Walisona Goro, on the northwest by Dawo, on the north by Elu, and on the east by Tole. The administrative town in Becho district is Tulu Bolo. The 2007 national census total populations of the district were 74,016, of whom 37,481 were men and 36,535 were women; 14,476 or $19.56 \%$ of its population were urban dwellers. The three largest ethnic groups exists in Becho were Oromo (90.32\%), Amhara (6.87\%), and Silte (1.66\%); all other 
Determinants of Demand for Credit among Wheat and Teff Smallholder Farmers in Central of Ethiopia (Arsi and South West Shewa)

ethnic groups made up $1.15 \%$ of the population. Oromiffa was spoken as a first language by $90.35 \%, 8.13 \%$ spoke Amharic, and $1.05 \%$ Silte; the remaining $0.47 \%$ spoke all other primary languages (CSA, 2007).

\section{Types, Sources and Methods of Data Collection}

Qualitative and quantitative types of data were collected from primary and secondary data sources. The primary data of both types were collected from sample farmers, by using semi-structured questionnaires and focus group discussion. Secondary data was taken from Central Statistical Agency (CSA), Bureau of Agriculture (BoARD), and Research Center and other sources.

\section{Theoretical Model Specification}

Demand is the willingness of a buyer, backed by money to buy a product. The demand for financial services, like other sort of product/service, is influenced by their own price and other factors such as level of income of borrower, and other costs related to borrowing. So far as financial services are concerned, interest charged is the price of credit. It is a believable assumption because when interest rate is high (price of credit), it discourages borrowers from taking up loans to avoid paying up high interest on the loan in the future. Specifically, in demand for credit analysis, other factors being constant, the higher the interest rate, the lesser will be the demand for credit (Paul, 2004).

Other determinants which also have positive correlation (according to set hypothesis) with demand for credit are income level, education, number of dependent schooling children and household size. It implies that higher income level, education, dependency ratio and household size will result in higher demand for credit and vice versa. The determinants which according to set hypothesis are negatively correlated are distance, age and loan delay (time gap between application and approval of loan). It means that higher the distance, age and loan delay lesser will be demand for credit and vice versa. So, in the study of determinants of credit demand of an individual is directed towards consumer behavior. In this study credit demand of an individual means the amount of money a teff grower is ready to borrow in order to fulfill his or her agricultural activity needs such as buying farm inputs, hiring extra labor for farming and cover costs related to agriculture activity including farm preparation, planting, weeding, harvesting and processing. Then level of demanded credit is defined as the amount in ETB of credit demanded by teff farmer.

The demand for credit can be expressed in an equation as follows:

$$
Y_{i}^{*}=X \mathrm{~b}+e_{\mathrm{i}}
$$

Where the subscript $i$ represents the amount of credit borrowed by household from formal or informal sources respectively. $\boldsymbol{X}$ is a vector of factors that would potentially influence the demand of credit sources. The subscript $\boldsymbol{i}$ indexes individual farmer households. $\boldsymbol{\beta}$ are slope parameters, and $\boldsymbol{e}$ are errors, assumed to follow normal distribution.

\section{Model specification}

The available data has analyzed by using frequency distribution, percentages, multiple regression analysis and t-test. T-test is employed in order to check the difference between credit needs of teff and wheat growers and supply of credit either by formal or informal credit providers. Multiple regression models has used for determining the major factors influencing demand of credit by teff and wheat farmers. Specifying the above formulation in equation for empirical investigation we got STATA Version-14 was used cross sectional data.

$$
\begin{aligned}
& Y i=\mathrm{a}+\mathrm{b}_{1} X_{1}+\mathrm{b}_{2} X_{2}+\mathrm{b}_{3} X_{3}+\mathrm{b}_{4} X_{4}+ \\
& \mathrm{b}_{5} X_{5}+\mathrm{b}_{6} X_{6}+\mathrm{b}_{7} X_{7}+\ldots \ldots . .+\mathrm{b}_{n} X_{n}+e_{i}
\end{aligned}
$$


Determinants of Demand for Credit among Wheat and Teff Smallholder Farmers in Central of Ethiopia (Arsi and South West Shewa)

\author{
Yi = Amount of credit demanded \\ $\alpha=$ Constant \\ $\checkmark$ Farming experience \\ $\checkmark$ Educational level \\ $\checkmark \quad$ Income level (ETB) \\ $\checkmark$ Farm size (hectare) \\ $\checkmark$ Family size \\ $\checkmark$ Dependency ratio \\ $\checkmark$ Interest rate (cost of borrowing) \\ $\checkmark$ Payback period \\ $\checkmark$ Distance from lender \\ $\checkmark$ Sources of credit \\ $\checkmark$ Access to extension service \\ $\checkmark \quad$ Total livestock unit \\ $\checkmark$ Sex of household head \\ $e_{i}=$ "Random error term independently and identically distributed with zero mean and constant variance" \\ Data has presented in the form of diagrams, tables, pie charts. On the basis of statistical results, correlation \\ between variables has organized. To evaluate interests of respondents, causal diagrams have been accomplished \\ from interviews and focus group discussions. STATA Version 14 has used for regression and other statistical \\ analyses.
}

\title{
RESUlt And Discussion
}

\section{Description of Factors of Teff Production and Supply}

\section{Demographics characteristics of teff farmers}

The demographic characteristics teff producers in terms of demand for credit were shown on Table 1. The average amount of credit demand by households is 3805 birr per household with standard deviation of 2286. There was a significant difference between above and below mean demand for credit in terms of gender at 10\% probability level.

Farm size of sample farmers varies from one hectare to 8 hectare. Land is major constraints that limit farmers' production potential in the study area. During survey, it was stressed that there was no option for newly formed households to have their own farmland. The only chance for such households was to share what the parent had in the past. The mean size of total land owned by teff producers who demand credit above and below mean was 2.4 hectare and 1.6 hectare per household with standard deviation of 1.54 and 1.24 respectively. In terms of total cultivation land owned by households there was significant difference between mean differences of demand for credit at $10 \%$ level of significance. The explanation for this result is that land is a scarce resource in the study area and it is more likely that those with bigger pieces of land resort to cultivated more crops such as chickpea, grass pea and wheat which leads to low teff production and hence the non-selling behavior.

From the total sampled farmers were about $73.33 \%$ of the farmers obtained credit in the survey year. The results from the survey show that among households, $91.53 \%$ have demand for credit above mean and about $6.25 \%$ of the households had demand for credit below mean. Credit is important for cushioning cash constrained farmers to be able to meet their farm activities requiring cash on time. Based on the chi-square test there is statistically significant difference between above and below of teff farmers at $1 \%$ probability level (Table 1). 
Determinants of Demand for Credit among Wheat and Teff Smallholder Farmers in Central of Ethiopia (Arsi and South West Shewa)

Table1. Demographics characteristics of teff producers

\begin{tabular}{|c|c|c|c|c|c|}
\hline \multirow{2}{*}{\multicolumn{2}{|c|}{ Variable }} & \multicolumn{3}{|c|}{ Demand for credit by teff farmers } & \multirow[b]{2}{*}{$\mathrm{t} / \mathrm{C}^{2}$-value } \\
\hline & & $\begin{array}{l}\text { Total } \\
(\mathrm{N}=150)\end{array}$ & $\begin{array}{l}\text { Above mean } \\
(\mathrm{N}=118)\end{array}$ & $\begin{array}{l}\text { Below mean } \\
(\mathrm{N}=32)\end{array}$ & \\
\hline \multicolumn{2}{|l|}{ Age of household head } & 46.70 & 46 & 49 & -0.88 \\
\hline \multicolumn{2}{|l|}{ Farming experience } & 25.47 & 25 & 27 & -0.86 \\
\hline \multicolumn{2}{|l|}{ Family size } & 7.24 & 7.21 & 7.34 & -0.31 \\
\hline Sex of household head & Male & 86.67 & 88.98 & 78.13 & $2.57^{*}$ \\
\hline \multicolumn{2}{|c|}{ Distance to money lender } & 9.60 & 9.60 & 9.61 & -0.01 \\
\hline \multicolumn{2}{|c|}{ Land allocated for teff } & 2.08 & 2.05 & 2.16 & -0.53 \\
\hline \multicolumn{2}{|c|}{ Total land owned } & 2.23 & 2.4 & 1.6 & $1.95^{*}$ \\
\hline \multicolumn{2}{|c|}{ Income from off-farm activity } & 2215.4 & 2190 & 2314.64 & -0.23 \\
\hline \multirow{2}{*}{ Literacy status } & Illiterate & 30 & 30.51 & 28.13 & \multirow{2}{*}{1.58} \\
\hline & Literate & 70 & 69.49 & 71.87 & \\
\hline \multicolumn{2}{|l|}{ Access to credit (Yes) } & 73.33 & 91.53 & 6.25 & $93.61^{* * *}$ \\
\hline \multicolumn{2}{|l|}{ Livestock holding } & 8.66 & 8.86 & 7.93 & 0.98 \\
\hline \multicolumn{2}{|l|}{ Teff production } & 19.21 & 19.54 & 18 & 0.66 \\
\hline \multicolumn{2}{|l|}{ Teff consumption } & 6.04 & 6.12 & 5.76 & 0.41 \\
\hline \multicolumn{2}{|c|}{ Cost of production per quintal (ETB) } & 664.44 & 653.30 & 705.18 & -1.09 \\
\hline
\end{tabular}

$* * *, * *$ and $*$ are statistically significant at $1 \%, 5 \%$ and $10 \%$ probability level, respectively.

Source: Generated from field survey data (2014)

\section{Demographics characteristics of wheat producers}

The survey results revealed that about $78.67 \%$ of the sample respondent's demanded credit above mean and about $21.33 \%$ farmers demanded credit below mean. The average teff growing experience of household head was 25 years, implying that famers have enough knowledge and competence in teff farming and making informed management choices. As indicated in Table 2, farmers demanding credit above mean is (27 years) had more farming experience than farmers who demand credit below mean (24 years). The independent test revealed that there is a significant difference at $10 \%$ level of significance in terms of farming experience between above and below mean of credit demanded by farmers. The average distance to nearest lender for farmers demanding credit above mean was 10.10 kilometers with standard deviation of 4.37 whereas 9.02 kilometers with standard deviation of 3.46 for farmers demanding credit below mean. This showed that farmers demanding credit above mean is far from the nearest market when compared with farmers demanding credit below mean. Between demand for credit below and above mean there were significant difference regarding distance to money lender at $10 \%$ significance level (Table 2). This finding was inconsistent with the finding Yehuala (2008) which studied the determinants of smallholder farmers access to formal credit: the case of Metema Woreda, north Gondar, Ethiopia and indicated that distance was not a limiting factor for credit access.

The study results revealed that access to credit improve the financial capacity of teff growers through purchase of inputs, hence increasing production which reflected in the marketable supply. This finding was in line with Hussain (2012) which studied the factors influencing demand for credit from formal and informal sources in Gujranwala district, Pakistan. 
Determinants of Demand for Credit among Wheat and Teff Smallholder Farmers in Central of Ethiopia (Arsi and South West Shewa)

As the study result showed in rural areas market information is limited in the Ethiopian grain market. Furthermore, at the producer level, farmers have very limited information on teff price prevailing even in nearby markets. Similarly, mixed farming whereby teff and animal keeping is the main activity that plays an important role in the identified area.

Table2. Factors of wheat farmers demand for credit

\begin{tabular}{|c|c|c|c|c|c|}
\hline \multirow{2}{*}{\multicolumn{2}{|c|}{ Variable }} & \multicolumn{3}{|c|}{ Demand for credit by wheat farmers } & \multirow[b]{2}{*}{$\mathrm{t} / \mathrm{c}^{2}$-value } \\
\hline & & $\begin{array}{l}\text { Total } \\
(\mathrm{N}=150)\end{array}$ & $\begin{array}{l}\text { Above mean } \\
(\mathrm{N}=80)\end{array}$ & $\begin{array}{l}\text { Below mean } \\
(\mathrm{N}=70)\end{array}$ & \\
\hline \multicolumn{2}{|c|}{ Age of household head } & 46.7 & 47 & 46 & 0.48 \\
\hline \multicolumn{2}{|l|}{ Family size } & 7.24 & 7.1 & 7.4 & -0.86 \\
\hline \multicolumn{2}{|c|}{ Sex of household head (Male ) } & 86.67 & 80 & 82.86 & 1.65 \\
\hline \multicolumn{2}{|c|}{ Teff farming experience } & 25.47 & 26.73 & 24.03 & $1.74^{*}$ \\
\hline \multicolumn{2}{|c|}{ Access to nearest market } & 9.6 & 10.10 & 9.20 & $1.65^{*}$ \\
\hline \multicolumn{2}{|c|}{ Land allocated for teff } & 2.08 & 1.9 & 2.28 & $-2.45^{* *}$ \\
\hline \multicolumn{2}{|c|}{ Income from off-farm activity } & 2215.47 & 2069.63 & 2420.18 & -0.79 \\
\hline \multirow{2}{*}{ Literacy status } & Illiterate & 30 & 31.25 & 28.57 & \multirow{2}{*}{2.38} \\
\hline & Literate & 70 & 68.75 & 71.43 & \\
\hline \multicolumn{2}{|c|}{ Access to credit (Yes) } & 73.33 & 68.75 & 78.57 & 1.84 \\
\hline \multicolumn{2}{|c|}{ Ownership of transport equipment (Yes) } & 74.67 & 73.75 & 75.71 & 0.07 \\
\hline \multicolumn{2}{|c|}{ Livestock holding } & 8.66 & 7.7 & 9.7 & $-2.65^{* * *}$ \\
\hline \multicolumn{2}{|l|}{ Teff production } & 19.21 & 18.93 & 19.54 & -0.32 \\
\hline \multicolumn{2}{|c|}{ Teff consumption } & 6.04 & 5.36 & 6.82 & $-2.07^{* *}$ \\
\hline \multicolumn{2}{|c|}{ Cost of production per quintal (ETB) } & 664.35 & 645.15 & 686.03 & -1.04 \\
\hline
\end{tabular}

***, $* *$ and $*$ are statistically significant at $1 \%, 5 \%$ and $10 \%$ probability level, respectively.

Source: Generated from field survey data (2014)

For farmer producing teff mean of demand for credit above and below mean of land allocated for teff production was 1.9 hectare and 2.28 hectare with standard deviation 0.83 and 1.04. There was a significant difference between the two categories with regard to land allocated for teff production at $5 \%$ probability level.

\section{ECONOMETRICS RESULT}

\section{Determinants of Demand for Credit among Wheat and Teff Smallholder Farmers}

The multiple linear regression model result indicated that about $91.1 \%$ and $82.4 \%$ variation in the model were due to the explanatory variable included in the model for wheat and teff producers respectively. As far the multiple linear regression models based on different assumption such as multicollinearity, hetroscedacity and model specification test were performed accordingly and the result implies that there were no such serious problems of multiple linear regression model assumptions. 
Determinants of Demand for Credit among Wheat and Teff Smallholder Farmers in Central of Ethiopia (Arsi and South West Shewa)

Table3. Multiple Linear Regression Model Result

\begin{tabular}{|c|c|c|c|}
\hline & & Wheat & Teff \\
\hline & VARIABLES & Coefficient & Coefficient \\
\hline & Sex of household & $-5.424^{* *}$ & -6.615 \\
\hline & & $(1.882)$ & $(6,704)$ \\
\hline & Farming experience & -0.0918 & 112.3 \\
\hline & & $(0.0498)$ & (282.4) \\
\hline & Family size & -1.372 & -769.2 \\
\hline & & $(0.797)$ & $(1.238)$ \\
\hline & Distance to money lender & 0.0144 & $2.094^{* * *}$ \\
\hline & & $(0.564)$ & $(6.318)$ \\
\hline \multirow{12}{*}{ Education status (base illiterate) } & Primary & 2.423 & 13.947 \\
\hline & & $(2.325)$ & $(16.336)$ \\
\hline & & $4.316^{*}$ & $19.274^{* *}$ \\
\hline & & $(2.066)$ & $(6.365)$ \\
\hline & Above & - & $10.285^{*}$ \\
\hline & & - & $(5.972)$ \\
\hline & Farm size & $0.0155^{*}$ & $-4.316^{*}$ \\
\hline & & $(0.00647)$ & $(2.407)$ \\
\hline & Income of household & $-0.700^{* *}$ & 2.083 \\
\hline & & $(0.274)$ & $(2.096)$ \\
\hline & Dependency ratio & - & $5.097^{*}$ \\
\hline & & - & $(2.687)$ \\
\hline \multirow[t]{2}{*}{ Payment time (base short time) } & Long Payment time & $1.955^{*}$ & 3.209 \\
\hline & & $(1.002)$ & $(1.925)$ \\
\hline \multirow{8}{*}{$\begin{array}{l}\text { Interest rate charged by lender } \\
\text { (base very low) }\end{array}$} & Low Interest Rate & $3.437^{* * *}$ & $18.526^{* *}$ \\
\hline & & $(0.909)$ & $(7.256)$ \\
\hline & Medium Interest Rate & $-4.106^{* *}$ & 6.094 \\
\hline & & $(1.253)$ & $(6.127)$ \\
\hline & High Interest Rate & $-5.900 * *$ & -6.035 \\
\hline & & $(2.190)$ & $(5.444)$ \\
\hline & TLU & - & -152.8 \\
\hline & & - & $(485.4)$ \\
\hline \multirow{9}{*}{ Sources of credit (Microfinance) } & Business partners & $-3.210^{*}$ & - \\
\hline & & $(1.541)$ & - \\
\hline & Local money lender & $-7.833^{* *}$ & $-25.331^{* *}$ \\
\hline & & $(2.648)$ & $(12.018)$ \\
\hline & Access to different training & $5.676^{* *}$ & 7.230 \\
\hline & & $(2.013)$ & $(4.667)$ \\
\hline & Constant & $22.88^{* * *}$ & -26.464 \\
\hline & & $(5.445)$ & $(21.705)$ \\
\hline & R-squared & 0.911 & 0.824 \\
\hline
\end{tabular}

Sources: Own Computation (2016)

The results depicted in the Table 3 were discussed as follows accordingly.

American Research Journal of Business and Management 
Determinants of Demand for Credit among Wheat and Teff Smallholder Farmers in Central of Ethiopia (Arsi and South West Shewa)

\section{ANNUAL INCOME OF HOUSEHOLD}

The significant and positive coefficient of the annual household incomes variable in the model suggests that annual household income generation decreases a farmer's demand for credit which contracting a loan from informal/formal sources of finance. Adding annual household income to a farm household's income portfolio decreases its chance of engaging in demand for credit markets by 70 percent. This result suggests that, given the lack of land tenure security or low annual income (Musahara, 2006) coupled with the unpredictable nature of farm incomes, off-farm activities play an important collateral function in the credit market in Rwanda. This finding vindicates studies conducted elsewhere such Kiiza and Pederson (2001) in Uganda, Oboh and Kushwaha (2009) in Nigeria, and Tang et al. (2010) in China. This finding, therefore, implies that poor farmers could be included more in demand for credit perhaps because they have appropriate collateral.

\section{Perception on interest rate charged}

Perception on interest rate charged variable is statistically significant at $1 \%$ and $5 \%$ level of significance for wheat and teff farmers respectively when the farmers perceive the interest rate charged is low. The coefficient has value of expresses that with perception on interest rate charged is low the amount of credit demand increases by 3.437 ETB and 18.526 ETB for wheat and teff farmers respectively. While perception on interest rate charged is high amount of credit demanded by farmers' decreases by 5.9 ETB and 6 ETB respectively. This is because of that farmers give much importance to interest rate charged but also give priority to sudden fulfillment of their credit demand.

\section{Sex of household}

Being a male-headed household, which increases the demand for credit by wheat farmers in the study area (this is not surprising because female-headed households are less likely to be land owner and therefore would prefer joining credit programs that lend for nonfarm businesses, which gives seasonal agricultural loans only). Gender of the borrower is an important factor for determining farmers demand for credit. Many studies find that women participate in informal finance more than men, especially in the savings side of the market (Tsai, 2004). Tsai (2004) on the other hand, attributes that to the better developed social networks of women with one another. In household level attributes the lower education levels of women, which make formal financial contracts difficult to understand while some studies argue that female entrepreneurs' are subject to a higher credit rationing in formal credit markets (Patton, 2005). Carter and Rosa (1998) finds that female entrepreneurs' relationships with bankers are weaker compared to men because of sexual stereotyping and discrimination.

\section{Access to extension service}

Amount of credit demand by smallholder farmers is positively and significantly affected by access to different extension service provided by developments agents in the study for wheat farmers. Access to different extension service would increase the awareness level of farmers and exposure to new ideas, information, activities, opportunities, working environment etc. Usually training programs which focus on credit may help borrowers to use the credit fund efficiently and to identify different source of income. Moreover the training may also help borrowers to understand their rights and obligation to use credit and to repay in time. Therefore, access to different extension service would have positive impact on the decision of farmers to repay their loan. Consistent with the findings of Sisay (2008) in Ethiopia, suggested that farm households which receive technical advice from extension agents are more likely to use formal credit.

\section{Repayment period}

This variable refers whether the existing time schedule for loan repayment is appropriate time for farmers to repay their loan or not. It is a dummy variable taking a value 0 , if it is appropriate i.e. given enough time 
Determinants of Demand for Credit among Wheat and Teff Smallholder Farmers in Central of Ethiopia (Arsi and South West Shewa)

for borrower to pay the loan and 1 otherwise. The coefficient of the variable may appear with positive sign in loan repayment for long repayment time that means when long repayment time arranged by lender the credit demand by wheat farmer increase by 1.95 ETB per month. In one hand as the due date for loan repayment is more approaches to time of harvesting or long enough, it may help farmers to repay their loan on time before they used their product for consumption or other purpose. On the other hand the variable may also increase default; this is because during harvesting time market price for farm product special for grain is relatively low then farmers may need extra time to repay their loan until market price start to rise.

\section{Distance to lender}

Coefficient of distance to credit providers is negative at low levels of credit demand and positive at its high levels by both teff and wheat farmers. It means that probability of having large demand for credit increase as farmers live somewhere far from the credit provider for teff production and this variable is insignificant for wheat farmers. Distance to credit providers affected farmers demand for credit positively at $1 \%$ significance level. This showed farmers worry to borrow money is not distance to credit provider than borrowing cost charged by lender. When distance from credit provider increase by one hour amount of credit demand by smallholder farmers increase by 2.094 birr. This may due to in the remote village where credit providers (formal credit provider) is far from smallholders farmers it is difficult for farmer to obtain credit from formal credit sources, then farmer is forced to borrow from lender who charged $100 \%$ interest rate.

\section{Education}

This variable is categorical variable. It means that by increasing the level of education, probability of having more demand for credit increases and the probability of having credit demand decreases at its low education levels for teff and wheat farmers. The years of formal education attained have a significantly positive effect on the amount of credit demanded by the farmers. The results show that a change in a wheat farmers 'formal education form primary to secondary education increases the demand for credit from 2.42 ETB to 4.316 ETB. This finding is supported by the results of Greuninget al. (1998).

Demand for credit is positively affected by secondary and above education status of household at $10 \%$ and $5 \%$ significance level for teff farmers. This showed that when household attended education above secondary school the demand for credit increased by 13.947 birr, while individual who attended secondary the demand for credit increased by 10.285 birr. This implies that household who attended above secondary school has more willingness for credit than individual who attend secondary school and below. This implies that higher levels of farmers' education are significantly associated with higher chances of participating in credit markets as borrower, ceteris paribus. This indicates that adding one level to a farmers' education increases his chances of borrowing money by 3.762 birr for teff farmers. This is due to the fact that educated farmers have a better understanding of borrowing procedures and rules for acquiring and using formal banking financial product and services. This may probably mean that literate farmers have more exposure to the external environment and information which helps them easily associate to credit sources. This finding is in line with the Nguyen (2003) the assertion that education is the most important factor affecting households' credit activities.

\section{Farm size}

Farm size affect both wheat and teff farmers significantly and positively at $10 \%$ significance level. The larger the land under cultivation, the bigger the demand for the credits as is typically expected to be the case in many least developed countries. Since land can be regarded as an income distribution criterion in the rural areas, the agricultural credit provider in the country should recognize and devote further micro-credit to small farmers considering land as collateral.The result is supported by the findings of Barslund and Finn (2003). 
Determinants of Demand for Credit among Wheat and Teff Smallholder Farmers in Central of Ethiopia (Arsi and South West Shewa)

The positive relationship between farm size and demand for credit is that farmer who owned larger size of land can utilize land as collateral to obtain more credit to buy capital for labor and other farm inputs and therefore, this will increase the demand for credit and therefore, as demand increase there will be a chance of access to credit. As the land owned by smallholder farmer increase by one hectare the demand for credit increased by 43.16 birr and it is statistically significant at $10 \%$ significance level. On other hand, since farming in rural Ethiopia is extensive and in extensive farming when the size of the land increases the need for labor proportionally increases. This again increases operational expenses, which leads to the need for additional capital, and additional capital requirement leads to the demand for credit.

However, this result is in line with the study of Miller and Ladman (1983) who applied discriminant analysis to identify a set of socio-economic, physical and psychological factors that influence credit use among small farmers with a view to differentiate between borrowers, potential borrowers, and non-borrowers. Interviews with teff growers show that small farmers and landlords don't have the same accessibility status. This is not without reason because landlords always have strong relations with credit providers. Besides it, since they have many acres of land, credit provider always give them priority due to less risk involvement. Credit providers prefer to give loan to only one landlord irrespective of giving to 5 to 10 small teff farmers. The study conducted by Victor et al. (2011) also showed that land plays a vital role as a collateral security for granting credit.

\section{Sources of credit}

The source of credit is also other independent variables that significantly affect the demand for credit by smallholder teff and wheat farmers in the study area at different significance level. When a farmer is not access to formal credit provider such as microfinance, bank and others the demand for credit decrease by 25.33 birr for teff farmer. Whereas for wheat farmers when farmers access to informal credit providers such as business partner and local money lender the demand for credit decrease by 3.21 ETB and 7.83 ETB than access to formal credit providers respectively. The results show that households which had access to informal credit had a lower probability of participating in formal credit than their counterparts. This influence suggests that farmers substitute formal credit sources for informal ones.

\section{Dependency ratio}

The dependency ratio is positively and statistically significant at $10 \%$ level of significance. The coefficient is showing that 1 percent increase in dependency ratio will bring 2.083 birr increase in demand for credit. The coefficient of regression has showed the result against hypothesis and determines negative relationship between credit demand and dependency ratio. This implies that farmers who have more dependency ratio take more loans to accommodate the live of his household and vice versa. However, a high dependency ratio exerts consumption stress on the household and lenders might be averse to lending to such households because of repayment ability of borrower, i.e. the credit might be channeled towards other uses rather than its intended productive purposes. Dependency ratio as a proxy for risk-bearing capacity con-firms that the higher the number of dependent household members, the more likely that the household are to suffer risk.

\section{CONCLUSION}

The role of agricultural credit in the development of agricultural sector is magnificent. Accessible credit enhances farmers' purchasing power to enable them acquire modern technologies for their farm production. Access to the credit however, seems to be limited among smallholder farmers due to certain constraints. Using the multiple regression models, the study sought to analyze the factors that influence households' demand for credit by farmers in Central parts of Ethiopia with much emphasis placed on the membership to farmers' associations. The impacts of household characteristics on credit demand, we estimate a multiple regression model. There is no uniform access to formal credit across rural communes in Ethiopia, although quantitative 
Determinants of Demand for Credit among Wheat and Teff Smallholder Farmers in Central of Ethiopia (Arsi and South West Shewa)

rationing does exist. The results showed that demand for credit by teff smallholders are affected positively by education status, dependency ratio, low interest rate, farm size and long payment period, while the sources of loan if it is business partner affected the amount of credit demanded by teff farmers negatively. The amount of credit demanded by wheat farmers were affected negatively by sex and sources of loan if it is business partner, whereas independent variables such as education status, farm size, long repayment period, low interest rate and access to training were affecting amount of credit demanded by wheat farmers positively. Results from the study showed that almost $50 \%$ of households have access to credit and that decision to access agricultural credit is significantly determined by sex of household, education status, low interest rate, and long repayment period, income of household, access to training and source of credit. We therefore call on stakeholders to streamline loan application procedures, intensify education of farmers on loan procedures and promote flexibility in types of collateral demanded by financial institutions to enhance access. In case of collateral security, farmers should be encouraged to form cooperative groups to enable them pull resources together or form groups to access loans from financial institutions since the group lending scheme ensures higher repayment rate as the leader of the group serves as a guarantor to the bank.

\section{REFERENCES}

Adera, A. 1995.Instituting effective linkages between formal and informal financial sector in Africa: A proposal. Savings and Development, 1: 5-22.

AssefaAdmassie, 1989. Some Factors Influencing Agricultural Credit, among Peasant Farmers in Ethiopia: A case study of two districts. Ethiopian Journal of Development Research, 11(1): 10.

Atieno, R. 2001. Formal and informal institutions' lending policies and access to credit by small-scale enterprises in Keya: An empirical assessment. African Economic Research Constortium, Nairobi.

Bigsten, A., Collier, p., Dercon, S., Fafchamps, M., Gauthier, B., Gunning, J.W., Oduro, A., Oostendrop, R., Patillo, C., Soderbom, M., Teal, F., and Zewfack, A.,, 2003. Credit constraints in manufacturing enterprises in Africa. Journal of African Economics 12(1): 104-125.

Briquette, 1999. Better practices in Agricultural lending, FAO publication

Buvinic, M. and Berger, M. 1990. Sex differences in access to small enterprise development fund in Peru. World Development, 18(5): 695-705.

Diagne, A. 2000.Measuring access to credit and its impacts on household food security: Some methodological notes. Paper presented at 2000 annual meeting of The American Agricultural Economic Association (AAEA), San Antonio, Texas.

Fleisig, H. 1995. The power of collateral. View point. Washington D.C., the World Bank.

Getaneh Gobezie, 2005a. Livelihoods through Micro-enterprise Services; Assessing Supply and Demand Constraints for Microfinance in Ethiopia (With Particular Reference to the Amhara Region); Paper Presented at the $3{ }^{\text {rd }}$ International Conference on the Ethiopian Economy, Organized by the Ethiopian Economic Association June 2-4, 2005. Addis Ababa, Ethiopia.

Hussain, T. (2012). Factors influencing demand for credit from formal and informal sources in Gujranwala district, Pakistan: a case of Commercial Banks and Arties (Master's thesis, Norwegian University of Life Sciences, Ås).

Hussien Hamda, 2007. Farm Household Economic Behaviour in Imperfect Financial Markets, Doctorial Thesis, Swedish University of Agricultural Sciences, Uppsala.

American Research Journal of Business and Management

Page 16 
Determinants of Demand for Credit among Wheat and Teff Smallholder Farmers in Central of Ethiopia (Arsi and South West Shewa)

Kashuliza, A.K. and J.G. Kydd. 1996. Determinants of bank credit access for small holder farmers in Tanzania: A discriminant analysis application. Saving and Development, 3: 285-97.

Kereta B, and Befekadu B. "Outreach and financial performance analysis of microfinance institutions in Ethiopia." African Economic Conference, Addis Ababa. 2007.

Lycette, Margaret A., and White K. 1989. "Improving women's access to credit in Latin America and the Caribbean: Policy and project recommendations," in Marguerite Berger and Mayra Buvinic (Eds.), Women's Ventures.West Hartford, CT: Kumarian Press.

McKee, K. 1989. Micro-level strategies for supporting livelihoods, employment, and income generation of poor women in the world: The challenge of significance. World Development, 17(7): 993-1006.

Miller, Calvin J and Jerry R. Ladman, 1983, Factors Impeding Credit Use in Small Farm Households in Bolivia. The Journal of Development Studies, 19(4): 523.

Mohieldin S. and Write W. 2000. Formal and informal credit markets in Egypt. Center for economic policy research and University of Nottingham.

Padmanabhan K.H. 1996. Rural credit, lessons for rural bankers and policy makers, London, UK.

Penchansky, R. and Thomas, W. J., 1981. The Concept of Access: Definition and Relationship to Consumer Satisfaction. Medical Care, 19(2): 127-140

Schmidt, P., and Kropp. 1987. The prediction of occupation using multiple logit models. International Economic Review 16: 471-486.

Singh, R.P. 1993. Segmentation and interest rate in rural credit markets: Some evidence from eastern Uttar Pradesh, India. Bangladesh j. agric. econs.14(2): 107- 117

Stevenson, L., 1986. Against all odds: The entrepreneurship of women. Journal of Small Business Management, 24(10): $30-36$.

TeferaDerbew, 2004. Determinants of smallholder farmers demand for non-formal credit: The case of FartaWoreda. Un published M.Sc thesis, Alemaya University, Ethiopia.

TesfayeAssefa, 1989. Rural Credit in Ethiopia, Addis Ababa, Ethiopia.

Yehuala, S. "Determinants of smallholder farmers access to formal credit: the case of Metema Woreda, north Gondar, Ethiopia." (2008).

Zeller, M. 1994. Determinants of credit rationing: A study of informal lenders and formal groups in Madagascar. World Development 22 (12): 1895-1907.

Citation: Efa Gobena Tura, Tadesse Kenea, Tura Kaso, Determinants of Demand for Credit among Wheat and Teff Smallholder Farmers in Central of Ethiopia (Arsi and South West Shewa). American Research Journal of Business and Management; V3, I1; pp:1-17

Copyright (c) 2017 Efa Gobena Tura, Tadesse Kenea, Tura Kaso, This is an open access article distributed under the Creative Commons Attribution License, which permits unrestricted use, distribution, and reproduction in any medium, provided the original work is properly cited.

American Research Journal of Business and Management

Page 17 